\title{
COMMUNICATION OF VILLAGE GOVERNMENT CRISIS IN THE COVID PANDEMIC 19 IN BIKUK AIR VILLAGE
}

\section{KOMUNIKASI KRISIS PEMERINTAH DESA DALAM MASA PANDEMI COVID 19 DI DESA AIR BIKUK}

\author{
Yanto \\ Program Studi IImu Komunikasi Fakultas IImu-IImu Sosial \\ Universitas Dehasen Bengkulu \\ Email: Yanto@unived.ac.id
}

\begin{abstract}
How to Cite :
Yanto, Y. (2020). Komunikasi Krisis Pemerintah Desa Dalam Masa Pandemi Covid 19 Di Desa Air Bikuk. SENGKUNI Journal- Social Sciences and Humanities. DOI:

https://doi.org/10.37638/sengkuni.1.1.12-23

\section{ARTICLE HISTORY}

Received [11 Maret 2020]

Revised [28 Maret 2020]

Accepted [8 April 2020]

KEYWORDS

Crisis

Communication

Village Government

Pandemic

This is an open access article under the $C C-B Y-S A$ license

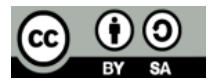

\section{ABSTRAK}

Menghadapi krisis virus seperti ini dalam bersamaan eskalasi ketidakpuasan masyarakat akan naik terus dapat berujung kepada krisis ketidak percayaan, selain dari itu kegaduhan informasi yang berakibatkan hilangnya rasa aman ditengah masyarakat, dengan demikian yang paling berperan dalam menjaga arus informasi itu tetap terjaga dengan baik adalah pemerintah desa, bagaimana mereka bisa mengendalikan dan menyampaikan informasi yang sehat, oleh karena itu tujuan dari penelitian ini adalah untuk melihat komunikasi krisis yang dilakukan oleh pemerintahan desa dalam masa pandemic covid-19 di Desa Air Bikuk. Adapun metode penelitian ini menggunakan kualitatif deskriptif, sebuah metode yang ingin mendeskripsikan keadaan dan fenomena yang ada ditengah masyarakat dengan menggunakan observasi wawancara dan dokumentasi sebagai alat pengumpulan data. hasil penelitian ini menunjukkan bahwa komunikasi krisis yang dilakukan oleh pemerintah desa Air Bikuk adalah dengan menyampaikan informasi dengan cepat dengan cara membuat tim dan posko, untuk menunjukkan rasa peduli dan rasa empati yang sungguhsungguh kepada masyarakat desa, dalam saluran komunikasi mereka menggunakan tatap muka dan spanduk dan selebaran, konsistensi mereka perlihatkan melalui selalu meghidupkan posko dan mendatangi orang-orang luar yang masuk diwilayah mereka dan keterbukaan terlihat mereka melakukan kerjasama dengan berbagai pihak seperti PT Agro Muko, dan membuat spanduk larangan untuk sholat di Mesjid, bagi para pendatang.

\section{ABSTRACT}

Facing a viral crisis like this in the same time escalation of public dissatisfaction will continue to rise can lead to a crisis of mistrust, apart from the information uproar that results in a loss of security in the community, thus the most important role in maintaining the flow of information is maintained properly is the village government, how they can control and convey healthy information, therefore the aim of this study is to look at crisis communication carried out by the village administration during the co-19 pandemic period in Air Bikuk Village. The method of this research uses descriptive qualitative, a method that wants to describe the conditions and phenomena that exist in the
\end{abstract}


community by using interview observation and documentation as a data collection tool. the results of this study indicate that crisis communication conducted by the Air Bikuk village government is to convey information quickly by creating teams and command posts, to show genuine care and empathy to the village community, in their communication channels using face-to-face and banners and leaflets, their consistency is shown by always turning on the post and visiting outsiders who enter their area and openness is seen as they collaborate with various parties such as PT Agro Muko, and make banners prohibiting prayers at the mosque, for migrants.

\section{PENDAHULUAN}

Dalam kehidupan bermasyarakat ataupun dalam sebuah organisasi di mana krisis dapat setiap saat terjadi. Potensi krisis akan tampak ketika ada trend negatif seperti yang terjadi pada tahun 2020 saat ini, seluruh dunia seketika tiba-tiba dihebohkan. Tidak ketinggalan Negara Indonesia menjadi imbas dari kehebohan tersebut, Negara Indonesia saat ini tercat menjadi peringkat ke 31 di seluruh dunia terkait penyebaran suatu virus yang bisa dibilang mematikan ini. (pikiran-rakyat.com17-juni-2020).

Virus ini disebut dengan COVID-19 yaitu Corona Virus Disease atau lebih dikenal dengan Virus Corona. Penyebaran virus ini terbilang sangat pesat sekali karena dalam kurun waktu yang cukup singkat ini penyebarannya sudah sampai ke berbagai wilayah di Indonesia.

keadaan ini sudah menjadi bencana dan gonjangan nasional yang menyeluruh dan merata dan menyasar di tengah masyarakat desa yang notabenya masih sedikit arus informasi yang mereka terima, dan dikuatirkan informasi yang mereka dapat tidak lengkap.

Dari observasi awal penulis lakukan di desa air bikuk mencatat 35 orang yang menjadi ODP (orang dalam pengawasan), yang semuanya nya tercatat baru pulang dari kota tetangga. Dan sampai detik ini belum ada yang positif terjangkit virus covid19, (Data Puskesmas Desa air bikuk).

Dalam menghadapi krisis virus seperti ini dalam bersamaan eskalasi ketidakpuasan masyarakat akan naik terus dapat berujung kepada krisis ketidak percayaan jika pemerintah dirasakan tidak sepenuhnya hadir kepada mereka. Pada dasarnya mereka adalah akar rumput yang mudah terbakar jika kepercayaan menipis.

Oleh karena itu pada saat krisis dibutuhkan menejerial yang tepat juga oleh sebuah organisasi dalam hal ini pemerintah desa, Oleh karena itu pemerintah Desa harus bertanggung jawab untuk menyampaikan informasi yang benar dan tepat.

Pada tataran praktis, tidak dapat dipungkiri kadang pemerintah dalam penanganan krisis seringkali tidak optimal. Disebabkan berbagai faktor seperti jumlah aparat yang terkadang tidak mencukupi, kendala geografis, jarak dan sumber daya lainnya.

Dalam hal ini komunikasi tidak dalam kontek mengendalikan virus akan tetapi mengendalikan informasi yang beredar ditengah masyarakat, bahwa masyarakat butuh informasi yang sehat, sehingga tidak terjadi kecemasan dalam menjalani kehidupan dan tidak terhambat aktifitas sehari-hari.

Krisis kadang tidak bisa dihindari akan tetapi bisa diminimalisir, dalam hal ini komunikasi krisis mencoba mengambil peran seperti dikemukan oleh Coombs \& Sherry (2010:20) mengatkan "crisis communication can be defined broadly as the collection, processing, and dissemination of information required to address a crisis situation." 
Artinya komunikasi krisis dapat di definisikan secara luas sebagai pengumpulan, pengolahan, dan penyebaran informasi yang di perlukan untuk mengatasi situasi krisis.

Ketika informasi yang tidak lengkap sering terjadi kekacauan, hal ini disebabkan arus informasi ada yang simpang siur seperti contoh ada berbagai penolakan jenazah yang heboh diberitakan diberbagai daerah di Indonesia dilansir dari kumparan.com ada warga yang menolak kedatangan jenazah. (kumparan.com/27/05/2020/).

Melihat fenomena diatas menjadi penting dan perlunya komunikasi yang dilakukan oleh pemerintah desa dalam mengendalikan informasi pada masa pandemic covid-19 ini penulis tertarik untuk melihat lebih jauh mengenai komunikasi krisis yang dilakukan oleh pemerintah desa.

Tujuan Penelitian untuk mendeskripsikan Komunikasi Krisis Pemeritah Desa Dimasa Pandemi Covid 19 Di Desa Air Bikuk Mukomuko Bengkulu.

\section{LANDASAN TEORI}

\section{Konsep Komunikasi dan Komunikasi Krisis}

Pengertian Komunikasi. Komunikasi dapat dilakukan secara langsung maupun menggunakan media. Contoh komunikasi langsung tanpa media adalah percakapan tata muka, pidato tatap muka dan lain-lain sedangkan contoh komunikasi menggunakan media adalah berbicara melalui telepon, mendengarkan berita lewat radio atau televisi dan lain-lain. Menurut Effendy (2003: 8), komunikasi dilakukan dengan tujuan untuk perubahan sikap (attitude change), perubahan pendapat (opinion change), perubahan perilaku (behaviour change) dan perubahan sosial (social change).

Menurut Trenholm dan Jensen (dalam Fajar, 2009: 31), komunikasi merupakan suatu proses dimana sumber mentransmisikan pesan kepada penerima melalui beragam saluran. Suatu proses yang mentransmisikan pesan kepada penerima pesan melalui berbagai media yang dilakukan oleh komunikator adalah suatu tindakan komunikasi. Selanjutnya menurut Weaver (dalam Fajar, 2009: 32), komunikasi adalah seluruh prosedur melalui pemikiran seseorang yang dapat mempengaruhi pikiran orang lain.

Effendy (2002: 60), menjelaskan bahwa komunikasi merupakan proses penyampaian suatu pesan dalam bentuk lambang bermakna sebagai pikiran dan perasaan berupa ide, informasi, kepercayaan, harapan, himbauan, dan sebagai panduan yang dilakukan oleh seseorang kepada orang lain, baik langsung secara tatap muka maupun tidak langsung melalui media, dengan tujuan mengubah sikap, pandangan atau prilaku.

\section{Komunikasi Krisis}

Menurut Fearn-Banks (2002:2) berpendapat bahwa "crisis communication is the dialog between the organization and its publics prior to,during, and after the negative occurrence". Yang artinya menyatakan bahwasannya krisis komunikasi adalah dialog yang terjadi antara perusahaan dan publik dalam waktu sebelum dan setelah krisis.

Coombs \& Sherry (2010:20) mengatkan "crisis communication can be defined broadly as the collection, processing, and dissemination of information required to address a crisis situation." Artinya komunikasi krisis dapat di definisikan secara luas sebagai pengumpulan, pengolahan, dan penyebaran informasi yang di perlukan untuk mengatasi situasi krisis. 
Menurut G. Harisson (2005), aktivitas public relations dalam menyediakan pesan-pesan yang relavan dengan situasi krisis dan membuka saluran komunikasi terbuka, disebut komunikasi krisis (communication crisis) (Kriyantono,2015:202).

Kalau melihat defenisi diatas maka kita bisa memahami bahwasannya komunikasi krisis ini sangat penting dilakukan oleh pemerintah, dalam hal ini pemerintah desa, untuk memberikan suatu informasi yang jelas, dan melakukan penyaringan terhadap informasi-informasi yang dibutuhkan.

Pentingnya komunikasi krisis sebagai bagian dalam krisis manajemen diungkapkan oleh sejumlah ahli. Coombs (seperti dikutip Kyhn, 2008) menyatakan bahwa komunikasi krisis adalah "darah kehidupan" dari seluruh kegiatan manajemen krisis dan memainkan peran vital di setiap tahap dari manajemen krisis. Pendapat lain yakni dari dari Fearn-Banks (seperti dikutip Kyhn, 2008) menjelaskan dalam manajemen krisis yang efektif terdapat komunikasi krisis yang tidak hanya mengurangi atau menghilangkan krisis, tetapi juga sedikit banyak dapat menghadirkan reputasi bagi organisasi yang lebih baik dibanding sebelum terjadinya krisis.

\section{Prinsip dalam komunikasi krisis}

Ada tiga prinsip utama dalam komunikasi krisis, yakni: menyampaikan pesan dengan cepat atau segera menyampaikan pesan, konsisten, dan terbuka (Coombs, 2006)

a. Menyampaikan pesan dengan cepat berarti memberikan kesempatan bagi pemangku kepentingan, terutama media massa, untuk mengetahui tentang apa yang sebenarnya terjadi. Tujuannya adalah mengisi kekosongan informasi ketika krisis berlangsung. Respon yang lambat justru memberikan kesempatan bagi pihak lain - terutama yang ingin menghancurkan reputasi organisasi atau perusahaan tersebut - untuk mengisi kekosongan informasi tersebut dengan spekulasi atau informasi yang salah. Respon yang cepat juga akan membentuk persepsi di mata public bahwa perusahaan atau organisasi tersebut dapat mengendalikan situasi. Akan tetapi, respon yang bersifat segera ini juga memiliki kelemahan. Coombs (dalam Soule, 2010) mengatakan kerugian utama dari respon cepat adalah tentu saja kecepatan meninngkatkan tingkat risiko yang dihadapi.

b. Konsisten, maksudnya adalah berbagai pesan yang disampaikan organisasi bebas dari kontradiksi. Dengan kata lain, konsistensi merupakan berbicara dalam satu suara. Memang tidak mungkin dalam situasi krisis hanya satu orang saja yang berbicara untuk mewakili perusahaan atau organisasi. Bagaimanapun, tim komunikasi krisis harus memastikan bahwa juru bicara yang berbeda akan memberikan pesan yang konsisten.

c. Keterbukaan. Menurut Coombs, prinsip ini merupakan satu-satunya prinsip yang kontroversial. Kontroversi muncul akibat interpretasi yang berbeda terhadap pemahaman keterbukaan ini. Interpretasi pertama adalah keterbukaan berarti orang-orang dalam organisasi (yang berwenang untuk memberikan pernyataan) selalu siap dan bersedia untuk berkomunikasi dengan para pemangku kepentingan, terutama media massa. Keengganan untuk berkomunikasi dengan pemangku kepentingan akan menimbulkan kesan bahwa organisasi tersebut sangat tertutup, berusaha menyembunyikan sesuatu, atau tidak mampu menangani krisis.

\section{Pengertian dan karakteristik krisis}

Ada tiga kondisi yang umum terjadi dalam krisis. Menurut Argenti (2009: 259), hal tersebut adalah: (1) elemen-elemen yang sifatnya tak terduga; (2) informasi yang tidak mencukupi; dan (3) begitu cepatnya dinamika yang terjadi. Sementara Millar \& Heath (2004) berpendapat bahwa dalam situasi krisis berita bisa menyebar begitu 
cepat yang berpotensi melumpuhkan jajaran manajemen sebelum mereka bisa mengontrol situasi dengan efektif.

Krisis bisa dibilang ibarat sebuah petaka atau bencana yang dapat muncul secara alami ataupun juga dari sebuah hasil kesalahan, intervensi bahkan nihat jahat manusia. Krisis juga dapat berupa kehancuran yang "nyata dan tidak nyata".

Menurut Machfud (1998), krisis adalah suatu kejadian, dugaan atau keadaan yang mengancam keutuhan, reputasi, atau keberlangsungan individu atau organisasi. Hal tersebut mengancam rasa aman, kelayakan dan nilai-nilai sosial publik, bersifat merusak baik secara aktual maupun potensial pada organisasi, dimana organisasi itu sendiri tidak dapat segera menyelesaikannya.

\section{Manajemen Krisis}

Menurut Iriantara (2004), manajemen krisis adalah salah satu bentuk saja dari ketiga bentuk respon manajemen terhadap perubahan yang terjadi di lingkungan eksternal organisasi. Manajemen krisis didasarkan atas bagaimana menghadapi krisis (crisis bargaining and negotiation), membuat keputusan di saat krisis (crisis decision making), dan memantau perkembangan krisis (crisis dynamics). Manajemen bertanggung jawab untuk mencari pemecah masalah dari krisis yang muncul dengan menggunakan strategi manajemen krisis yang mungkin dilakukan.

Prinsip pertama dalam manajemen krisis yaitu berorientasi pada keselamatan publik, Public Relations juga menerapkan strategi komunikasi krisis yang dirumuskan dengan:

Mengurangi resiko muncul kepanikan publik,

> Mengurangi kekhawatiran yang dirasakan publik,

> Mengurangi spekulasi-spekulasi khususnya diawal-awal krisis,

$>$ Melindungi perusahaan dari kritik-kritik spekulasi yang biasanya muncul dari diskursus publik di media masa, Bersifat dapat dipercaya (accountability), keterbukaan (disclosure),dan komunikasi berbasis keseimbangan kepentingan (symmetrical communication), Didesain untuk meminimalkan kerusakan pada citra organisasi. (Kriyantono, 2012:189).

\section{Konsep Tahapan Komunikasi Krisis}

Beberapa cara berkomunikasi dengan media yang dapat dilakukan oleh Public Relations, diantaranya (Kriyantono, 2012:205-207) :

a. Membuka akses informasi setiap saat dibutuhkan oleh media

b. Membuka akses wartawan untuk berkomunikasi dengan top management

c. Selalu menyampaikan informasi secara jujur

d. Antisipasi pertanyaan dari media massa sehingga Public Relations mempunyai kesiapan informasi menyangkut isu-isu yang diprediksi akan menjadi incaran media

e. Langsung memberi informasi secepatnya pada saat krisis mulai berlangsung

f. Informasi harus konsisten

g. Sampaikan apa yang dirasakan organisasi tentang krisis dan tindakan apa saja yang sudah dilakukan oleh organisasi untuk meminimalkan dampak krisis

h. Menganggap bahwa apapun yang diomongkan Public Relations jika di dengar media, mempunyai potensi untuk dimuat di media tersebut.

i. Media tidak dapat diabaikan selama krisis 
j. Usahakan menjadikan organisasi sebagai satu-satunya sumber informasi yang mempunyai otoritas penuh dalam menyampaikan informasi yang akurat

k. Monitoring berita-berita media

\section{Konsep Masyarakat Desa}

Pengertian dan Ciri Masyarakat Desa. Menurut Soerjono Soekanto (2006: 166167) masyarakat pedesaan pada hakikatnya bersifat gradual. Warga suatu masyarakat pedesaan memupunyai hubungan yang lebih erat dan lebih mendalam ketimbang hubungan mereka dengan warga masyarakat pedesaan lainnya. Sistem kehidupannya berkelompok atas dasar sistem kekeluargaan. Penduduk masyarakat desa pada umumnya hidup dari pertanian, walaupun terlihat adanya tukang kayu, tukang membuat genteng dan bata, tukang bangunan, akan tetapi inti pekerjaan penduduk pedesaan adalah pertanian. Masyarakat ditandai oleh ciri-ciri, yaitu adanya interaksi, ikatan pola tingkah laku yang khas didalam semua aspek kehidupan yang bersifat mantap dan kontinyu, dan adanya rasa identitas terhadap kelompok, dimana individu yang bersangkutan menjadi anggota kelompoknya.

\section{Media Komunikasi Desa}

Bentuk komunikasi di pedesaan lebih cenderung kepada komunikasi antar personal. Yaitu proses pertukaran informasi di antara seseorang dengan paling kurang seorang lainnya atau biasanya diantara dua orang yang dapat langsung diketahui balikannya.

Terdapat tiga media yang sangat berpotensi dalam penyebaran informasi di pedesaan, yaitu : pertama Koran masuk desa adalah media massa atau Koran kota yang dikelola untuk masyarakat desa. Kedua media rakyat adalah media profil pedesaan yaitu dari, oleh, dan untuk rakyat pedesaan tetapi belum ada di Indonesia. Dan yang ketiga adalah media tradisional.

\section{Pemerintah Desa}

Pemerintahan desa memiliki peranan signifikan dalam pengelolaan proses sosial dalam masyarakat. Tugas utama yang harus diemban pemerintah desa adalah bagaimana menciptakan kehidupan demokratik, memberikan pelayanan sosial yang baik sehingga dapat membawa warganya pada kehidupan yang sejahtera, rasa tentram dan berkeadilan

Desa juga memiliki hak dan kewajiban yang tertuang dalam Undang-Undang Nomor 6 Tahun 2014 tentang Desa yakni, Desa berhak: a. Mengatur dan mengurus kepentingan masyarakat berdasarkan hak asal- usul, adat-istiadat, dan nilai sosial budaya masyarakat desa; b. Menetapkan dan mengelola kelembagaan desa; c. Mendapatkan sumber pendapatan;

Desa berkewajiban; a. Melindungi dan menjaga persatuan, keatuan serta kerukunan masyarakat desa dalam rangka kerukunan nasional dan keutuhan Negara Kesatuan Republik Indonesia; b. Meningkatkan kualitas kehidupan masyarakat desa; c. Mengembangkan kehidupan demokrasi; d. Mengembangkan pemberdayaan masyarakat desa; dan e. Memberikan dan meningkatkan pelayanan kepada masyarakat desa.

\section{METODE PENELITIAN}

\section{Jenis Penelitian}


Penelitian ini menggunakan Jenis pendekatan penelitian kualitatif. Penelitian kualitatif ditujukan untuk mendeskripsikan dan menganalisis fenomena, peristiwa, aktivitas sosial, kepercayaan, persepsi, dan pemikiran orang secara individual ataupun kelompok. Bungin (2003:302) mengatakan, pendekatan kualitatif memusatkan perhatian pada prinsip-prinsip umum yang mendasari perwujudan sebuah makna dari gejala-gejala sosial di masyarakat. Objek analisisnya adalah arus komunikasi dalam penyampaian informasi pada masa covid 19 di tengah-tenah masyarakat yang dilakukan oleh pemerintahan desa air bikuk.

Sumber Data, dalam hal ini yang menjadi sumber data adalah semua yang diperoleh dari responden langsung dari orang-orang atau sumber pertama. yang diperoleh dari pemerintah desa dan dokumen-dokumen, arsip-arsip, catatan-catatan, gambar-gambar terkait dengan penelitian ini. Teknik Pengumpulan Data, teknik pengumpulan data merupakan langkah yang paling strategis dalam penelitian, karena tujuan utama dari penelitian adalah mendapatkan data. Dalam usaha pengumpulan data serta keterangan yang diperlukan dalam penelitian ini adalah penulis menggunakan metode pengumpulan data melalui obeservasi, pengamatan dan pencatatan secara sistematis terhadap gejala yang tampak pada objek penelitian. Dalam malakukan observasi ini penulis akan menyatakan terus terang kepada sumber data, bahwa sedang melakukan penelitian. Jadi mereka yang diteliti mengetahui sejak awal sampai akhir tentang aktivitas peneliti.(Sugiono, 2005:66). Wawancara, proses memperoleh keterangan untuk tujuan penelitian dengan Tanya jawab sambil tatap muka antara pewawancara dengan responden atau orang yang diwawancarai dengan atau tanpa mengunakan pedoman (guide). Bungin (2003:108). Dokumentasi, setiap bahan tertulis atau film dari record yang tidak dipersiapkan karena adanya permintaan dari seorang penyelidik. metode dokumenter merupakan pengumpulan data yang diperoleh dari berbagai catatan atau arsip penting. Guba dan Lincol (Moleong 2000:161)

\title{
Teknik Analisis Data
}

Langkah yang diambil dalam teknik analisis data dalam penelitian ini ialah menggunakan analisis data kualitatif oleh model interaktif Miles \& Huberman (1992:20). Dimana analisis, yang dilakukan ialah pengumpulan data terdiri atas tiga alur kegiatan yang terjadi secara bersamaan yaitu : reduksi data, penyajian data, penarikan kesimpulan/verifikasi.

\section{HASIL DAN PEMBAHASAN}

\begin{abstract}
Hasil
Kata Krisis sudah tidak asing lagi bagi kita, ketika kita mendengar kata krisis secara spontan pasti tertuju pada suatu permasalahan yang terjadi, Krisis tidak dapat dihindari, tapi kemungkinan masih bisa dicegah. Untuk mengantisipasi dan menghindari dari dampak negatif dari krisis yang terjadi diperlukan komunikasi krisis untuk menjaga rasa aman mengenai penyebaran virus, setelah penulis melakuakan berbagai pengamatan dan wawancara mengenai komunikasi krisis yang dilakukan oleh pihak pemerintah desa dengan melakukan sesuai dengan prinsip komunikasi krisis:
\end{abstract}

\section{Menyampaikan Pesan Dengan Cepat}

Pada dasarnya arus komunikasi dan arus informasi di pedesaan tidak secepat yanga ada di perkotaan, informasi dipedesaan tergolong lambat karena beberapa fakto diantaranya sinyal yang masih belum terlalu bagus, dan ditambah lagi tidak begitu 
tertarik orang dengan informasi yang ada di luar daerah meraka, informasi yang paling cepat didapat itu adalah anak-anak muda yang biasa bermain dimedia sosial.

Sehubungan dengan informasi yang berkaitan dengan virus korona kepanikan itu sudah mulai muncul karena ada beberapa berita yang tidak falid yang diterima oleh sebagian masyarakat didapatkan di media sosial diantaranya bahwa virus ini disebarkan melalui udara.

seperti yang disampaikan oleh sekretaris desa iwan menjelaskan:

"Sebenarnya masyarakat desa ini pada awalnya tidak terlalu heboh dengan berita korona, karena ada berita-berita yang belum tentu kebenaranya yang bikin heboh". sehingga kami harus mengambil tindakan dan sudah menjadi tanggung jawab kami untuk menyampaikan informasi yang benar dan cepat sebelum informasi yang ada salah dipahami" (wawancara iwan 20 juli 2020),

Dari pemaparan diatas dapat dipahami bahwa pemerintah desa mengambil tanggung jawab mengenai informasi yang akan dikembangakan dan langsung mengadakan pertemuan dalam hal ini pemerintah desa bersama tokoh masyarakat untuk melakukan tindak lanjut kedaaan ini agar lebih terpusat.

"Tidak lama setelah pertemuan kami mendirikan posko keamanan kovid dan membuat tim relawan" (Iwan 29 juni 2020).

Gambar diatas menunjukkan kesiapan para relawan dan pemerintahan desa dalam menunjukkan rasa peduli dan rasa empati yang sungguh-sungguh kepada masyarakat desa sehingga semua informasi yang tidak jelas dapat didiskusikan langsung dengan para tim relawan.

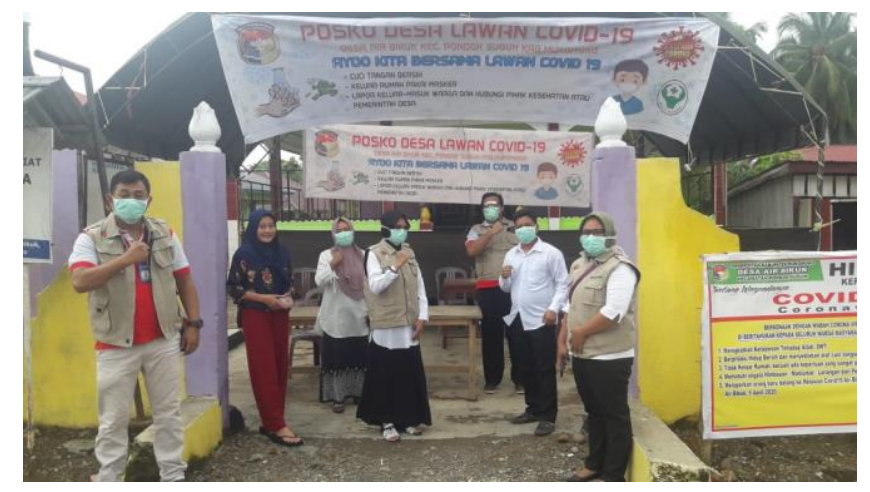

\section{Saluran Komunikasi}

Dalam menyampaikan pesan kepada masyarakat seperti halnya kehidupan didesa informasi itu banyak didominasi oleh komunikasi tatap muka, komunikasi langsg dengan warga, damun selaindari itu media komunikasi modern juga digunakan seperti penggunaan spanduk.

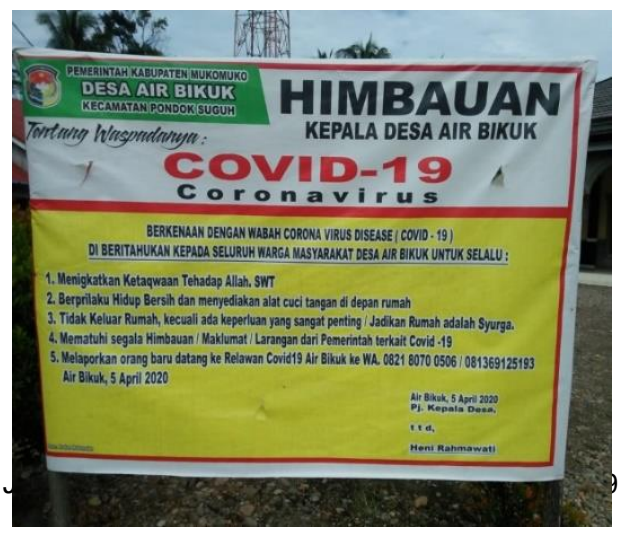




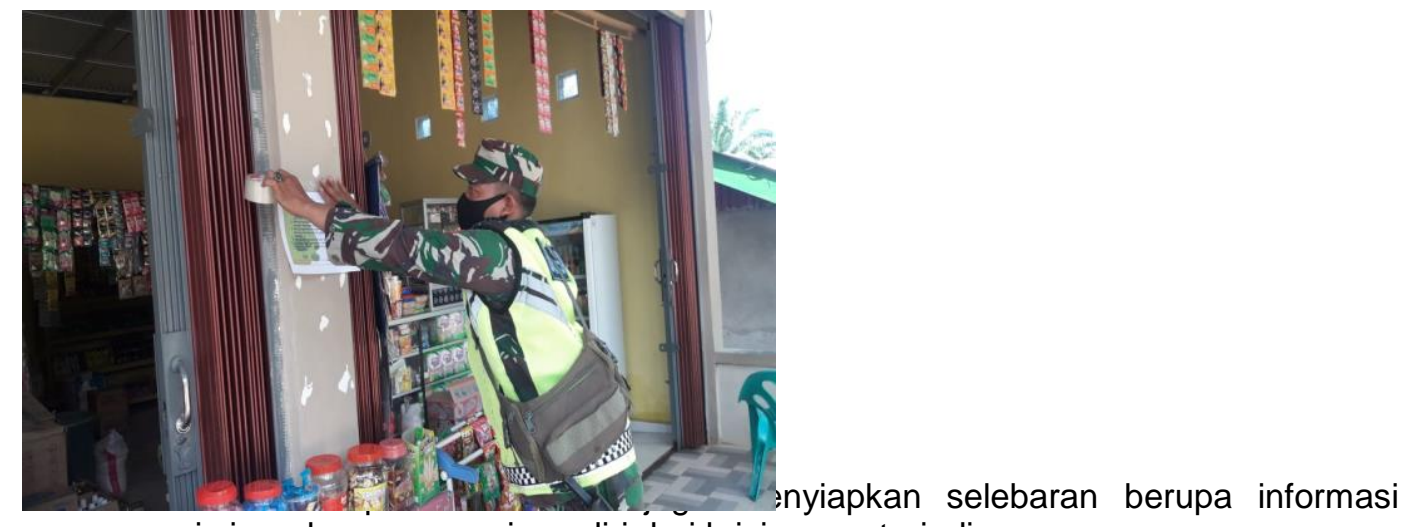
mengenai virus dan cara menjaga diri dari krisis yang terjadi.

\section{Konsisten:}

Menunjukkan konsistensi perhatian dan tanggung jawab atas krisis yang melanda ini ditunjukkan dengan tim relawan sangat aktif menjaga posko.

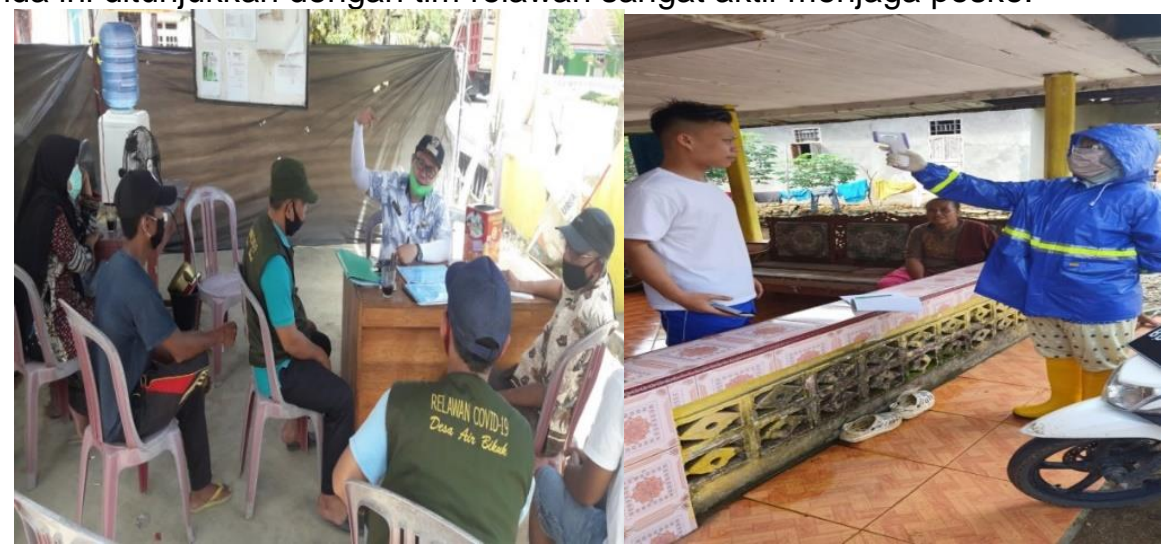

Salah satu keseriusan yang ditampakkan oleh para relawan dan pemerintah desa untuk menjaga rasa aman dari virus dengan mendatangi salah satu warga yang datang dari luar daerah mereka, dengan demikian tidak ada lagi fitnah dan berita yang tidak benar mengenai orang yang datang dari luar.

\section{Terbuka:}

Dalam masa krisis seperti ini sifat terbuka pada berbagai pihak sangat dibutuhkan dan menjalin kerjasama dengan stecholder yang ada diselingkungan desa juga dibutuh, seperti yang telah dilakukan oleh pemerintah desa mengajak PT agro muko untuk sama-sama bertanggung jawab dengan keadaan seperti saat ini. seperti yang disampaiakn oleh anggota BPD, bahwa penyewaan tarup untuk posko relawan covid itu semuanya dibayar oleh pt agro muko

"Tarup posko ini semua biaya sewa akan dibayar oleh PT" ujar Ali

Selain dari tu sifat terbuka juga terlihat untuk para pendatang yang biasa berhenti untuk melakukan ibadah sholat telah dipasang spanduk larangan untuk sementara tidak dulu berhenti dan sholat dimesjid. 


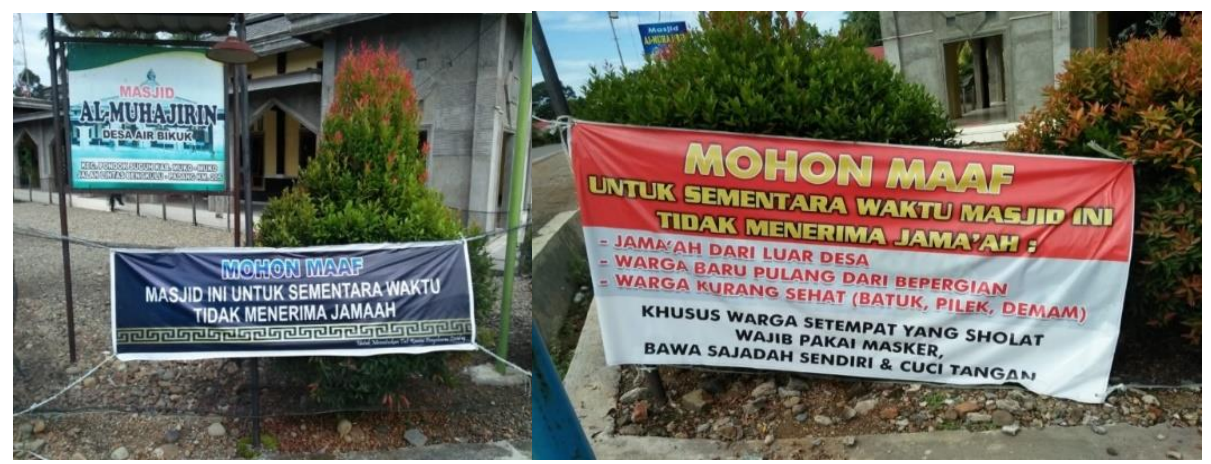

\section{Pembahasan}

Prinsip pertama dalam manajemen krisis yaitu berorientasi pada keselamatan public, komunikasi krisis yang dirancang dengan (1) mengurangi resiko muncul kepanikan public (2) mengurangi kekhawatiran yang dirasakan public (3) mengurangi spekulasi-spekulasi khususnya di awal-awal krisis.

Oleh karena itu Dalam komunikasi krisis, masyarakat sangat butuh informasi publik yang jelas dan memberi harapan. Dalam situasi krisis dan kedaruratan, "setiap kata (menjadi) penting". Demikian Barbara Reynolds dan Matthew Seeger dalam Crisis and Emergency Risk Communication: 2012 Edition. "Tugas kita sebagai komunikator kesehatan dan darurat masyarakat adalah menawarkan informasi yang dibutuhkan dan melawan perilaku berbahaya.

Dalam tahap komunikasi krisi kita mengenal ada yang dinamakan pra-krisis, komunikasi krisis berkisar mengumpulkan informasi tentang risiko krisis, membuat keputusan tentang bagaimana mengelola potensi krisis dan melatih orang-orang yang akan dilibatkan dalam proses penangan krisis. Pelatihan tersebut mencakup pembentukan anggota tim krisis, juru bicara dalam krisis, dan setiap individu yang terlibat dalam respon krisis. Komunikasi krisis mencakup pengumpulan dan pemrosesan informasi untuk mengeluarkan keputusan dan pesan krisis. Coombs (2010:20).

Komunikasi tidak berhenti saat krisis saja, tapi tetap berlangsung pasca krisis yang melibatkan pembedahan upaya manajemen krisis, mengkomunikasikan perubahan yang diperlukan pada individu, dan memberikan pesan krisis lanjutan sesuai kebutuhan, seperti yang terjadi saat ini pemeritah telah mengeluarkan maklumat new normal yang artinya msayarakat mulai hidup dengan gaya baru, yang lebih bersih dan sehat, dan itu juga menjadi tanggung jawab pemerintah desa dalam menyampaikan informasi mengenai pola hidup sehat.

Untuk memenuhi prinsip komunikasi krisis sangat memperhatiakan bagaimana pesan yang berkembang ditengah masyarakat untuk segera mengambil alih agar bisa menunjukkan rasa peduli dan rasa empati yang sungguh-sungguh dari pihak pemerintahan desa terhadap masyarakat yang terkena dampak krisis. Karena publik akan lebih menerima dan memberikan dampak positif apabila pemerintahan menunjukkan kesungguhan dan perhatiannya atas krisis yang sedang terjadi, Saluran Komunikasi Membuka saluran-saluran komunikasi dengan semua pihak yang terdampak oleh krisis. membuat banyak pilihan dalam mendapatkan Sering kali terjadi kebersinggungan antara aspek komunikiasi.

Komunikasi krisis memang mesti menggunakan pendekatan komunikasi dan unsur-unsur yang ada dalam saluran komunikasi. untuk memberikan informasi kepada 
public. agar krisis tidak semakin memburuk. oleh sebab itu pesan haruslah jelas, padat, tidak ambigu dan manis didengar oleh publik.

Selanjutnya konsisten Ini merupakan elemen dimana semua pihak pemangku kekuasaan menunjukkan konsistensi perhatian dan tanggung jawab atas krisis yang melanda. Ketika krisis sudah terjadi, maka semua pihak pernyataan yang sama. Maksudnya disini adalah ada keseragaman informasi di internal sehingga pesan yang disampaikan kepada publik adalah yang sebenarnya. Elemen ini merupakan output dari manajemen krisis tahapan awal before the crisis dimana manajemen telah menginternalisasi semua pihak.

Untuk keterbukaan Pesan yang disampaikan kepada publik haruslah jelas, mudah dipahami, sederhana dan tidak ambigu. agar pesan tidak diplintir sedemikan rupa sehingga berkembang informasi yang salah. Kita harus ingat bahwa di era digital ini orang bisa saja mengolah kembali informasi yang sebenarnya menjadi berita hoax yang malah akan memperkeruh suasana krisis dalam perusahaan menyampaikan kerjasama dengan pihak terkait dalam menyelesaikan krisis. Pada dasarnya, permerintah desa haruslah mengembangkan kerjasama dengan berbagai pihak, kontribusi terhadap lingkungan sosial sebagai dukungan ketika terjadi krisis, sehingga bisa meredam informasi negatif yang mungkin saja berkembang dalam masyarakat atas kriris yang melanda.

\section{KESIMPULAN DAN SARAN}

\section{Kesimpulan}

Dari hasil penelitian dan mengamatan mengenai komunikasi krisis pemerintah desa dalam masa pandemic didesa air bikuk dapat disimpulkan:

komunikasi harus cepat berjalan sebelum informasi yang benar dan salah bercampur terlalu lama sehingga menimbulkan ketidak percayaan pada siapapun oleh karena itu Menyampaikan pesan dengan cepat sangat dibutuhkan, dan pemilihan saluran dengan baik dan efektif dilakukan dengan tatap muka dan media modern. konsisten perlu dilakukan,agar berbagai pesan yang disampaikan organisasi bebas dari kontradiksi. Dengan kata lain, konsistensi merupakan hal yang mutlak. Keterbukaan selalu siap dan bersedia untuk berkomunikasi dengan para pemangku kepentingan dan stecholder.

\section{Saran}

untuk pemerintah desa semoaga kedepan bisa menentukan satu juru bicara yang bisa menjadi perwakilan dari pemerintahan.

peneliti selanjutnya bisa melihat pola komunikasi setelah krisis, bahwa setiap terjadi krisis kehidupan itu tidak akan kembali normal seperti sedia kala.

\section{DAFTAR PUSTAKA}

Basrowi. 2005. Pengantar Sosiologi. Depok: Ghalia Indonesia

Bungin, Burhan. 2003. Metode Penelitian Kualitatif. Jakarta, PT Raja Grafindo Persada. Coombs, Timothy W. 2006. "Crisis Management: A Communicative Approach". Public Relations Theory II. Carl H. Botan \& Vincent Hazelton (eds.). Mahwah: Lawrence Erlbraum Associates.

http://relagusmita.blogspot.com/2008/05/sistem-komunikasi-pedesaan.html

Iriantara, Yosal. 2004. Manajemen Strategis Public Relations. Jakarta: Ghalia Indonesia. 
Jurnal Runtiko dkk, krisis dan komunikasi pada masyarakat miskin perdesaan, 2015

Kriyantono, R. (2012). Public Relations \& Krisis Management: Pendekatan Critical Public Relations Etnografi Kritis \& Kualitatif. Jakarta: Kencana Prenada Media Group.

Kyhn, Helene Stavem. 2008. Situational Crisis Communication Theory: Its

Machfudz, D.M. 1998. Ketika Perusahaan Menghadapi Krisis. Jurnal ISKI Manajemen Krisis, No.2, Oktober 1998.

Marhaeni Fajar, IImu Komunikasi Teori \& Praktik Yogyakarta: Graha IImu, 2009.

Narayana Mahendra Prastya Komunikasi Krisis di Era New Media dan Social Media, ugm 2011

of Dash 8-Q400 Airlines. Master Thesis. Aarhus School of Business. http://pure.au.dk/portal-asbstudent/ files/3900/Helene_Stavem_KyhnMaster_Thesis.pdf, diakses 19 November 2011.

Onong Uchjana Efendy, IImu, Teori dan Filsafat Komunikasi, Bandung: PT. Citra Aditya Bakti, 2003

Prayudi. 2008. Manajemen Isu - Pendekatan Public Relations. Yogyakarta: Pustaka Adipura.

Putra, I Gusti Ngurah. 1999. Manajemen Hubungan Masyarakat. Yogyakarta: Universitas Atma Jaya Yogyakarta.

Soekanto, Sudjono. (2006). Sosiologi Suatu Pengantar. Jakarta: PT. Raja Grafindo Persada

Suharsimi, Arikunto. 2006. Prosedur Penelitian. Bandung, Rosda Karya

Sukmadinata, Nana Syaodih. 2012 Metode Penelitian Pendidikan. Bandung, Remaja Rosdakarya

Use in A Complex Crisis with Scandinavian Airlines' Grounding. 